Revista Mídia e Cotidiano

Artigo Seção Livre

Número 10, Dez. 2016

Submetido em: 09/05/2016

Aprovado em: 27/10/2016

\title{
A RETÓRICA MIDIÁTICA COMO GATILHO DE EMOÇÕES ARQUETÍPICAS
}

\section{THE MEDIA RHETORIC AS TRIGGER FOR ARCHETYPAL EMOTIONS}

\section{Fernando Simões ANTUNES JUNIOR ${ }^{1}$}

Resumo: Este artigo parte dos pressupostos teóricos de Carl Jung sobre os arquétipos e o inconsciente coletivo, suas funcionalidades na estruturação da psique humana e a necessidade inata de vivenciá-los nas práticas cotidianas para estabelecer interfaces com a comunicação. Busca-se, através da análise de alguns construtos simbólicos do Portal G1, entender como os arquétipos podem ser eliciados pela retórica midiática para disparar emoções e, assim, criar necessidades, desejos e vontades nos indivíduos.

Palavras-chave: Comunicação; Emoções; Arquétipos.

Abstract: This article is based on Carl Jung's theoretical assumptions about the archetypes and the collective unconscious, their functionalities in the structuring of the human psyche and the innate need to experience them in daily practices to establish interfaces with communication. Through the analysis of some symbolic constructs of the G1 Portal, we seek to understand how archetypes can be elicited by mediatic rhetoric to trigger emotions and thus create needs, desires and wishes in individuals.

Keywords: Communication; Emotions; Archetypes.

Doutor em Comunicação Social pelo PPGCOM da PUCRS, membro do Grupo de Pesquisa Comunicação, Emoção e Conflito (GPCEC/PUCRS) e professor os cursos de graduação em Jornalismo e Publicidade e Propaganda da Faculdade São Francisco de Assis / feuantunes@gmail.com. 


\section{míDiA \\ ec DiAno}

\section{Introdução}

Para a neurociência, o pensamento é fruto do complexo sensação-emoção-razão, e a transposição deste complexo para a linguagem passa pelo que Aristóteles (2013) chamou de retórica. Falar em retórica significa versar sobre "efeitos de persuasão". Para os neurocientistas, a retórica é a propriedade linguística que cria as condições de emocionalidade para a interpretação do discurso. É ela que cria o contexto e dá o clima para a interpretação dos atos de fala. Costa (2007) infere que qualquer enunciado implica em um contexto inserido em uma sentença. E se há contexto, por mais sutil que se represente, há emoção. Contexto, portanto, é aquilo que interfere sobre a forma para impactar no conteúdo.

A retórica empregada em qualquer construto simbólico é constituída das intenções de seu autor. Ele escolhe determinadas palavras, utiliza sons e imagens e elabora seus argumentos esperando que a capacidade de empatia do receptor entre em ação para que a mensagem seja captada da maneira como imaginou. O pré-requisito da empatia, ou seja, esta capacidade inerente de sentir pelo outro, exige que uma mesma matriz simbólica seja compartilhada.

Algumas correntes teóricas do estudo das emoções entende existir uma base emocional presente na psique humana que facilitaria este processo de reconhecimento empático pela retórica. Seriam pulsões inatas responsáveis por muitos dos padrões humanos de comportamento, a qual a neurociência chama de metaprogramas mentais (DAMÁSIO, 2010).

O psicólogo norte-americano Paul Ekman (2011) detectou em suas pesquisas, por exemplo, que alguns medos humanos, como o medo de alguns insetos e répteis, incorrem na psique de forma instintiva. Seria uma herança evolutiva da espécie humana responsável por acionar dispositivos emocionais para nos colocar em um determinado estado de ação frente a supostos perigos naturais. Da mesma forma, respondemos de maneira instintiva a determinadas paisagens, como a paisagem do rosto e suas inúmeras expressões faciais. Um bebê é capaz de responder, por espelhamento, a um sorriso, e sentir a alegria do indivíduo espelhado por estar supostamente pré-programado a reconhecer as emoções e responder a elas. 
Ekman, tal qual Damásio (2010) e outros estudiosos das emoções, acreditam que toda emoção que se manifesta por cognição, ou seja, por forma experienciada ou herdada, possui um dispositivo acionador, um estímulo sensorial que vai encontrar correlações dentro da cognição do sujeito para acionar a emoção mais adequada para o momento. "É evidente como as variações idiossincráticas, ou seja, os gatilhos emocionais de cada pessoa, são adquiridas. Elas são aprendidas, refletindo a vivência de cada um de nós (um assaltante ou um porco-do-mato)" (EKMAN, 2011, p. 41).

No entanto, Ekman assume que existem gatilhos emocionais universais, comuns a todos os seres humanos, e usa uma série de estudos do psicólogo sueco Arne Ohman, que estudou um suposto medo ancestral que os humanos armazenam em seu sistema de aranhas e cobras, para fazer esta afirmação.

\begin{abstract}
Ohman deu um choque elétrico (tecnicamente denominado estímulo não condicionado), pois produz excitação emocional sem que haja aprendizado), justamente com um estímulo relevante - que desperte medo - (cobra ou aranha) ou irrelevante (cogumelo, flor ou objeto geométrico). Após a aplicação de apenas um choque em combinação com um dos estímulos relevantes, as pessoas sentiram medo quando uma cobra ou aranha foi mostradasem aplicação do choque, ao passo que, com relação aos estímulos não relevantes (flor, cogumelo ou objeto geométrico), foram necessárias mais associações com o choque para que o medo se manifestasse sem a aplicação do estímulo. As pessoas também continuavam com medo de cobra ou aranha, enquanto o medo da flor, do cogumelo ou do objeto geométrico se desvanecia (Ibid., p. 44).
\end{abstract}

Partindo da suposição de que a evolução e a seleção natural seriam os motivadores de uma programação inata para o medo de cobras e aranhas em nosso ambiente natural ancestral, Ohman teria lançado um contra-argumento de que se esta capacidade de armazenamento de gatilhos emocionais for real, as pessoas deveriam reagir a outros objetos perigosos que integram o nosso ambiente natural há gerações, tais como armas de fogo e tomadas elétricas.

No entanto, Ohman não constatou isso. Levou tanto tempo para condicionar o medo com relação a armas de fogo e tomadas elétricas quanto para condicionar o medo relacionado a flores, cogumelos e objetos geométricos. (Ibid., p. 45)

Ekman argumenta que talvez não estivemos expostos o suficiente a armas de fogo e tomadas elétricas para que a seleção natural os classificassem como gatilhos 
universais, mas se declara convencido de que uma das características mais distintivas das emoções é que os eventos que as ativam são influenciados não somente por experiências individuais, mas também por um passado ancestral da espécie.

\begin{abstract}
Nossos autoavaliadores são poderosos e examinam continuamente, fora de nosso conhecimento consciente, os temas e as variações dos eventos relevantes para nossa sobrevivência. Utilizando uma metáfora informática, os mecanismos automáticos de avaliação estão buscando em nosso ambiente algo que se assemelhe ao que está armazenado em nosso banco de dados de alerta emocional, escrito, de um lado, por nossa biologia, mediante a seleção natural, e, de outro, por nossa experiência individual. (Ibid., p. 46)
\end{abstract}

É em cima desta suposição de uma referência ancestral, anterior a própria vida do sujeito, que pretende-se estabelecer uma interface com os escritos de Carl Jung sobre o que chamou de arquétipos.

\title{
Gatilhos emocionais arquetípicos
}

Os estudos da mente de Ekman e alguns pressupostos da psicologia junguiana apresentam conceitos e embasamentos aos quais é possível se estabelecer interfaces para um maior entendimento do funcionamento das emoções no sistema psíquico humano. Jung (2011), ao realizar pesquisas com diferentes culturas ao redor do mundo e ao longo da história, defendeu que existem estruturas inatas na parte inconsciente da mente. Essas estruturas se apresentam em forma de imagens, símbolos e temas universais presentes na psique dos indivíduos. A estas imagens-referências ele deu o nome de arquétipos, ou tipos arcaicos. Podemos inferir, a priori, que o inatismo é um evidente pressuposto presente tanto nos estudos de Ekman quanto nas pesquisas de Jung. Uma base inferencial que destoa do famoso conceito da tábula rasa, de John Locke, que acreditava ser a mente humana uma tela em branco e que todas as ideias nascem da experiência.

Arquétipo, na origem epistemológica da palavra, significa "o primeiro modelo". Jung usou o termo porque deduziu que tais estruturas servem de matriz para a expressão e desenvolvimento da psique. Os arquétipos funcionariam como os primeiros filtros de percepção do mundo, ao mesmo tempo em que determinam padrões de comportamento dentro da espécie. 
Para o autor, os arquétipos formam a base do que chamou de inconsciente coletivo, que seria a parte mais profunda do inconsciente, presente e compartilhada por todos os indivíduos. Os arquétipos seriam, portanto, nossos metaprogramas primordiais, responsáveis por nossos instintos de sobrevivência e por nossas pulsões a executar determinadas ações no ambiente. Para Jung (1991, p. 206),

[...] ele [o homem] traz dentro de si certos tipos de instintos a priori que the proporcionam a ocasião e o modelo de sua atividade, na medida em que funcionam instintivamente. Como ser biológico, ele não tem outra alternativa, senão a de se comportar de maneira especificamente humana e realizar o seu pattern of behavior ${ }^{2}$. Isto impõe estreitos limites às possibilidades de ação de sua vontade, tanto mais estreitos, quanto mais primitivo ele for e quanto mais sua consciência depender da esfera dos instintos.

Os arquétipos seriam, tal qual as emoções, reguladores sempre presentes e biologicamente necessários. Assim como o organismo físico precisa de alimentos para sobreviver, o corpo psíquico carece vivenciar enredos arquetípicos para sustentar a psique do sujeito em suas interações com o meio. É da necessidade de vivência dos arquétipos e da respectiva correspondência a esta necessidade que a cognição se desenvolve para a formação da identidade.

Para Jung, é dos arquétipos que nascem nossas ações intuitivas. São "decorrentes de processos inconscientes que culminam em uma ideia súbita, a irrupção de um conteúdo inconsciente na consciência" (Ibid., p. 136). O autor entende a intuição como um processo análogo aos instintos, apenas com a diferença de que "enquanto o instinto é um impulso predeterminado que leva a uma atividade extremamente complicada, a intuição é a apreensão teleológica de uma situação, também extremamente complicada" (Ibid., p. 136).

Tal qual as emoções, e por estarem diretamente ligados a elas, ora acionando-as e ora sendo acionados por elas, os instintos são respostas automáticas, alheios às motivações conscientes, disparados por um impulso natural cego, sem deliberação prévia e sem a percepção consciente do que se está fazendo. "A ação instintiva, portanto, aparece mais ou menos como um acontecimento psíquico abrupto, uma

\footnotetext{
2 Padrão de comportamento.
} 
espécie de interrupção da continuidade de consciência. Por isso, é sentida como uma 'necessidade interior'" (Ibid., p. 134).

Para Jung, os instintos não podem ser tratados psicologicamente sem que se leve em conta os arquétipos, pois um condiciona o outro. É da analogia entre eles que se formam os padrões de comportamento.

\begin{abstract}
O instinto da formiga-cortadeira [saúva] realiza-se na imagem da formiga, da árvore, da folha, do corte, do transporte e no pequeno jardim de fungos, cultivado pelas formigas. Se falta uma destas condições, o instinto não funciona, porque não pode existir sem sua forma total, sem sua imagem. Uma imagem desta natureza constitui um tipo apriorístico. É inato na formiga, antes de qualquer atividade, porque esta só tem lugar quando um instinto de forma correspondente oferece motivo e possibilidade para isto. Este esquema vale para todos os instintos e apresenta forma idêntica em todos os indivíduos da mesma espécie. (Ibid., p. 206)
\end{abstract}

Tal qual no exemplo da formiga, sempre que a psique humana se depara com uma imagem ou símbolo arquetípico, uma série de emoções são ativadas para nos colocar em um determinado estado de ação ou padrão de comportamento. Diz Jung: "Na medida em que os arquétipos intervêm no processo de formação dos conteúdos conscientes, regulando-os, modificando-os e motivando-os, eles atuam como instintos" (Ibid., p. 210).

Na mesma direção que o exemplo da formiga, sempre que a psique humana se depara com uma imagem ou símbolo arquetípico, uma série de emoções são ativadas para nos colocar em um determinado estado de ação ou padrão de comportamento.

A representação dos arquétipos se dá por imagens e símbolos, conteúdos que Jung distingue entre "naturais", derivados da psique mais arcaica, cujas ideias e imagens são encontradas nos mais antigos registros das mais primitivas sociedades; e "culturais", que passaram por inúmeras transformações e longos processos de elaboração para expressarem "verdades eternas" em determinadas culturas das "sociedades civilizadas" (Id., 2008, p. 117). O que nos permite estabelecer mais uma interface com as conceituações de Ekman sobre gatilhos emocionais universais, portanto, inatos, e gatilhos emocionais aprendidos.

Murray Stein (2006), atribui aos arquétipos um extraordinário poder para influenciar a consciência de um modo tão eficiente quanto os instintos. 
Quando o ego depara com uma imagem arquetípica, pode ser por ela possuído, sobrepujado, e render-se-lhe mesmo querendo resistir-lhe, pois a experiência é percebida como algo sumamente fecundo e significativo. A identificação com imagens e energias arquetípicas constitui a definição de Jung de inflação e até, em última instância, psicose. [...]Em contraste com o impacto dos instintos sobre a psique - quando a pessoa se sente impelida por uma necessidade física - a influência dos arquétipos leva ao arrebatamento com ideias e visões grandiosas. Ambos afetam dinamicamente o ego de um modo semelhante, na medida em que, de uma forma ou de outra, ele é dominado, possuído e levado a agir. (Ibid., p. 93)

Segundo Stein, tanto Freud quanto Jung acreditavam que todo sujeito possui uma produção de energia psíquica que está destinada ao desenvolvimento da psique. A diferença entre ambos é que Freud chamava esta energia de libido, e defendia que todos os processos de acúmulos e dissipações desta energia estavam relacionados ao desejo sexual que os filhos alimentam inconscientemente pelos pais. Jung entendeu esta energia de forma distinta ao perceber que seus pacientes tinham necessidades de vivências que muitas vezes eram alheias aos desejos sexuais, mas que se encaixavam em enredos arquetípicos.

Da mesma forma que o corpo precisa de movimentos específicos para desenvolver os tecidos musculares, a psique necessita de vivências específicas para amadurecer. Os arquétipos, portanto, seriam figuras metafóricas criadas por nossa mente inconsciente para manifestar à mente consciente suas necessidades de vivência com o propósito de amadurecimento.

Estes símbolos, sejam eles naturais ou culturais, podem evocar reações emotivas profundas. Constituiriam uma espécie de matriz de gatilhos emocionais universais, que por sua vez, podem desencadear processos empáticos que originam ações e comportamentos.

Ao explorar a história da evolução humana, traçando muitos paralelos com alguns de seus pacientes, Jung estabeleceu o mito do herói, ao qual atribuiu uma importância primordial na formação da consciência. O arquétipo do herói, ou da criança-herói, seria um padrão humano básico, que implica em eliciar estados emocionais para lidar com rupturas. Desde o nascimento, onde há a ruptura com o ventre da mãe, passando por outras fases de rompimento ao longo da vida, como a ida para a escola, a universidade, a ruptura com o lar paterno/materno, e outras saídas da zona de conforto, o arquétipo do 


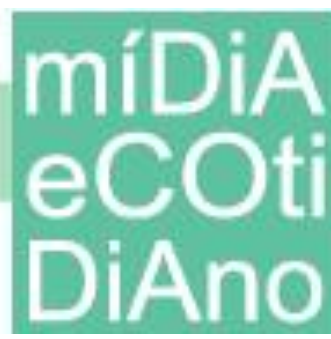

herói exige o abandono de pensamentos fantasiosos infantis para colocar o sujeito em condições de lidar com a realidade (Ibid., p. 86).

Ao mesmo tempo em que o arquétipo do herói é correspondido quando o indivíduo centra sua energia psíquica para a superação das rupturas, ele também é correspondido por outras sensações inerentes ao herói, como a necessidade de ajudar ao outro. Isto implica na existência de personagens secundários do enredo, como a vítima da situação de ruptura, ou a revelação de um elemento provocador de possíveis rompimentos, uma nêmesis que, no caso do herói, se personifica na figura do vilão (JUNG, 2011).

Joseph Campbell constatou estas pré-disposições ao conceber a obra $O$ herói de mil faces (1995), onde percebe que grandes narrativas cinematográficas seguem um mesmo roteiro de forma a desenvolver a jornada do herói nas telas do cinema, uma narrativa também recorrente na construção dos mitos.

O sucesso dos chamados blockbusters ${ }^{3}$ se explica, para além de fatores como qualidade técnica, estética ou narrativa, pelo cuidado em comum que todos estes filmes tiveram em proporcionar ao espectador a vivência de experiências arquetípicas. O acionamento de estados empáticos se dá pela identificação de signos ancorados nestas narrativas, e o sujeito receptor é levado a se associar inconscientemente aos personagens que eliciam um "rosto empático arquetípico" em sua psique.

\section{A retórica midiática para eliciar estados arquetípicos}

Quando estudou a importância dos arquétipos no cinema, o psicólogo estadunidense Skip Dine Young (2014, p. 44-45) percebeu que “[...] há um desejo de vivenciarmos as figuras arquetípicas a todo instante da vida cotidiana, como símbolos ressonantes de uma esfera psíquica emocional que nos conecta a um 'mundo mais elevado"”.

Young estudou o que chama de "fenômeno do imitador", onde há um acionamento tão empático das emoções arquetípicas em determinadas pessoas que estas desenvolvem

\footnotetext{
3 “Arrasa-quarteirão", na tradução livre. O termo é utilizado como gíria para descrever filmes de
} enorme sucesso no cinema estadunidense. 


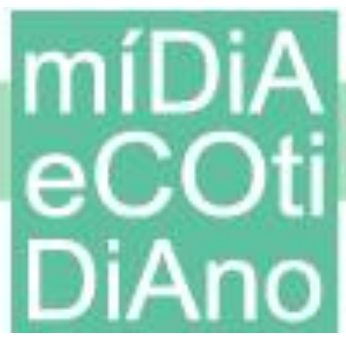

sintomas de trauma, depressão e psicose, como se vivessem no próprio filme. Joan Ferrés (1998), por sua vez, aborda o anseio do telespectador em viver a vida do mito como um envolvimento de sedução irracional, como compensações das próprias limitações e carências.

Campeões de bilheteria como Avatar (2009) e os filmes da saga Star Wars são recheados de personagens arquetípicos, que surgem a partir da jornada do herói, e dão vazão a outros arquétipos, como as figuras do curador (aquele que sobrevive às chagas da vida e, portanto, tem o conhecimento da cura), do mestre (aquele que transmite os conhecimentos e aprendizados), do visionário (aquele que enxerga padrões e consegue planejar o futuro), da grande mãe (a referência espiritual que proporciona a sensação de pertencimento a algo maior que a individualidade), etc. (STEIN, 2006).

A evidência destes arquétipos e sua ordem de surgimento e importância ficam perceptíveis em qualquer análise rasa. Em Avatar, por exemplo, o protagonista é um exsoldado cadeirante chamado Jake Sully (o herói e o curador ferido) que vive em um futuro desconhecido onde os humanos já conseguem fazer viagens espaciais e exploram recursos de outros planetas com fins comerciais. Quando é enviado à lua Pandora, Jake trabalha junto a um exército de exploradores que estão encontrando dificuldades em extrair minérios valiosos devido à resistência do povo nativo humanoide conhecido como Na'vi. Jake então, por conexão mental, assume o controle de um avatar, um corpo alienígena idêntico ao dos habitantes locais. Quando entra em contato com Naytiri, uma nativa de Pandora, Jake descobre o significado de Eywa, o cultuado espírito do planeta (arquétipo da grande mãe). Em sua jornada, conhece mentores (o mestre e o sábio) que vão lhe ajudar na compreensão de si mesmo e de valores há muito esquecidos pela espécie humana.

Em outra análise rápida, desta vez sobre a saga Star Wars, nos deparamos com o protagonista Luke Skywalker (o herói), que tem a família assassinada e é guiado por um monge jedi chamado Obi Wan Kenobi (o mestre) em uma jornada em busca de suas origens e de reconexões com uma entidade universal denominada de "A Força" (a grande mãe). Durante a aventura, conhece personagens que vão representar outros arquétipos estudados na psicologia Junguiana, como Han Solo (o fora-da-lei), a Princesa 


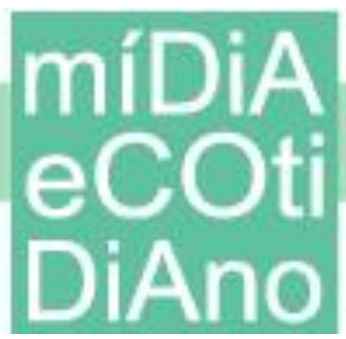

Leia (a donzela em perigo), Darth Vader (a sombra do herói), mestre Yoda (o mago) e assim por diante.

Conforme os gatilhos emocionais universais são ativados pela narrativa fílmica, nos associamos empaticamente aos personagens que melhor correspondem a este banco de imagens arquetípico. Enquanto o enredo do herói elicia emoções necessárias à superação de limites e obstáculos, o enredo do mago evoca estados criativos. Por sua vez, o enredo da grande mãe elicia um estado amoroso de aceitação e pertencimento em contrapartida ao estado de medo eliciado pelo enredo do vilão. Nesta miscelânea de enredos, emoções são disparadas e as vivências arquetípicas ocorrem por empatia aos personagens e suas histórias. Processos psíquicos que Jung (1991) vai classificar como fundamentais na solução de experiências como a carência, o vazio e a finitude.

Somos seduzidos pelos arquétipos e seus enredos específicos a ponto de criarmos rituais onde nos seja possível interpretá-los e vivenciá-los, seja no cinema, na publicidade, nos esportes ou nos rituais religiosos. Margaret Mark e Carol Pearson (2001) realizaram um estudo que identifica o uso das necessidades arquetípicas na construção de grandes marcas. Nele apontam 12 arquétipos frequentemente usados pela indústria para eliciar estados de empatia nos consumidores, para os quais encontram correlatos no mundo das estrelas e dos esportes a fim de dar um rosto ao processo empático.

São eles o criador, o prestativo, o governante, o bobo da corte, o cara comum, o amante, o herói, o fora-da-lei, o mago, o inocente, o explorador e o sábio. No estudo, as autoras detalham o enredo de cada arquétipo na psique e sua "função compensatória", bem como explicam como podem ser explorados na publicidade (Quadro 1).

Quadro 1: Arquétipos, funções e marcas.

\begin{tabular}{l|l|l}
\hline Arquétipo & Ajuda as pessoas a ... & Marcas que usam \\
\hline Criador & Criar algo novo & Willians Sonoma \\
\hline Prestativo & Ajudar os outros & AT\&T (Ma Bell) \\
\hline Governante & Exercer o controle & American Express \\
\hline Bobo da corte & Se divertirem & Miller Lite \\
\hline Cara Comum & Estarem bem assim como são & Wendy’s \\
\hline
\end{tabular}




\begin{tabular}{|c|c|c|}
\hline Arquétipo & Ajuda as pessoas a ... & Marcas que usam \\
\hline Amante & Encontrar e dar amor & Hallmark \\
\hline Mago & Influir na transformação & Calgon \\
\hline Inocente & Manter ou renovar a fé & Ivory \\
\hline Explorador & Manter a independência & Levi's \\
\hline Sábio & Compreender o mundo em que vivem & Oprah's Book Club \\
\hline
\end{tabular}

Fonte: MARK e PEARSON, 2001, p. 27.

Para cada figura arquetípica, as autoras atribuem um lema, um enredo que serve de diretriz para a construção dos significados que as marcas desejam passar, como mostra o Quadro 2.

Quadro 2: Lemas arquetípicos.

\begin{tabular}{l|l}
\hline Arquétipo & Lema \\
\hline Criador & "Se puder ser imaginado, poderá ser criado" \\
\hline Prestativo & "Ama teu próximo como a ti mesmo" \\
\hline Governante & "O poder não é tudo... é só o que importa" \\
\hline Bobo da corte & "Se eu não puder dançar, não quero tomar parte da sua Revolução" \\
\hline Cara Comum & "Todos os homens e mulheres são criados iguais" \\
\hline Amante & "Só tenho olhos para você" \\
\hline Herói & "Onde há vontade, há um caminho" \\
\hline Fora-da-lei & "As regras foram feitas para serem quebradas" \\
\hline Mago & "Pode acontecer!" \\
\hline Inocente & "Somos livres para ser você e eu” \\
\hline Explorador & "Não levante cercas à minha volta" \\
\hline Sábio & "A verdade libertará você" \\
\hline
\end{tabular}

Fonte: MARK e PEARSON, 2001.

Tal qual no cinema e na publicidade, figuras arquetípicas também são frequentemente eliciadas na narrativa jornalística. Como explica Jung (2011), um contexto de ruptura é a condição primeira para a evocação do arquétipo do herói, e o 


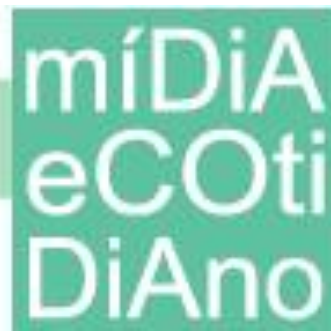

jornalismo se constrói de eventos desta natureza. Nas manchetes de jornais e revistas, bem como nas chamadas televisionadas, a composição sujeito-verbo-predicado funciona para atrair a atenção do leitor a partir de rupturas geralmente alarmistas, de forma que o receptor possa identificar rapidamente os atores associados à jornada do herói que se estabelece na narrativa para assumir uma posição empática. Ao estabelecer enredos de ruptura, a narrativa jornalística elicia o arquétipo do herói, que necessita da existência de outros personagens para existir, como o vilão e a vítima.

Uma rápida análise de dois eventos midiáticos de grande repercussão jornalística o rompimento de uma barragem no município de Mariana, em Minas Gerais; e os atentados em diversos pontos turísticos e culturais de Paris, na França - permitem constatar o estabelecimento deste enredo específico por parte da imprensa na construção de imagens arquetípicas para gerar empatia. Na figura 1, temos a chamada do Portal G1 em 13 de novembro de 2015, que noticia os atentados em Paris, com um vídeo do Jornal Nacional. $\mathrm{Na}$ abertura do telejornal, o apresentador Willian Bonner anuncia que "A Europa volta a ser alvo do Terror", apresentando uma ruptura pelo discurso, onde vítima e carrasco são estabelecidos, criando condições para a criação e/ou o surgimento da imagem arquetípica do herói na mente do receptor.

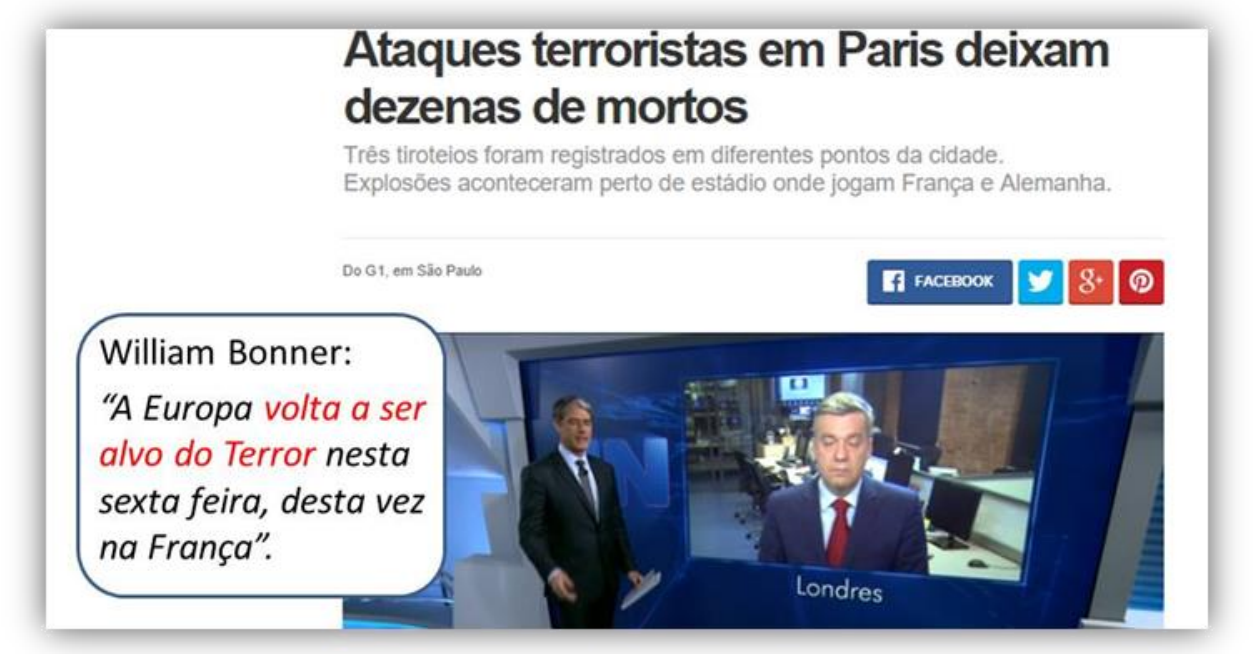

Figura 1: Screenshot Willian Bonner anuncia o Terror em Paris

Fonte: Portal $G 1^{4}$.

4 Disponível em <http://goo.gl/awS8Z2>. Acesso em 02/02/2016. 
O estabelecimento de um contexto de "terror" faz com que as propriedades arquetípicas emocionais do receptor comecem a rastrear o cenário em busca de um personagem ou elemento salvador, que devolva o ponto de equilíbrio à narrativa apresentada. Uma expectativa é criada, mas não resolvida. Não obstante, no dia 16 de novembro, o presidente francês François Hollande anuncia um pacote de medidas para combater o terrorismo, dentre elas a formação de uma coalizão com Estados Unidos e Inglaterra para "localizar, imobilizar e destruir" um inimigo "sem rosto" identificado apenas como Estado Islâmico.

A manchete do G1 (Figura 2) estabelece então os heróis e anuncia suas jornadas, preenchendo a expectativa gerada pela chamada do Jornal Nacional, o que vai servir de base para uma aderência empática por parte do leitor frente ao inimigo. $\mathrm{O}$ acionamento de tais papéis gera uma incapacidade nos espectadores de eliciarem empatia pelo inimigo, visto que há uma generalização que o coloca como o próprio terror, com seguidores sem identidade e, portanto, incapazes de provocar um rosto empático para que ocorra uma compreensão mais profunda de suas motivações.

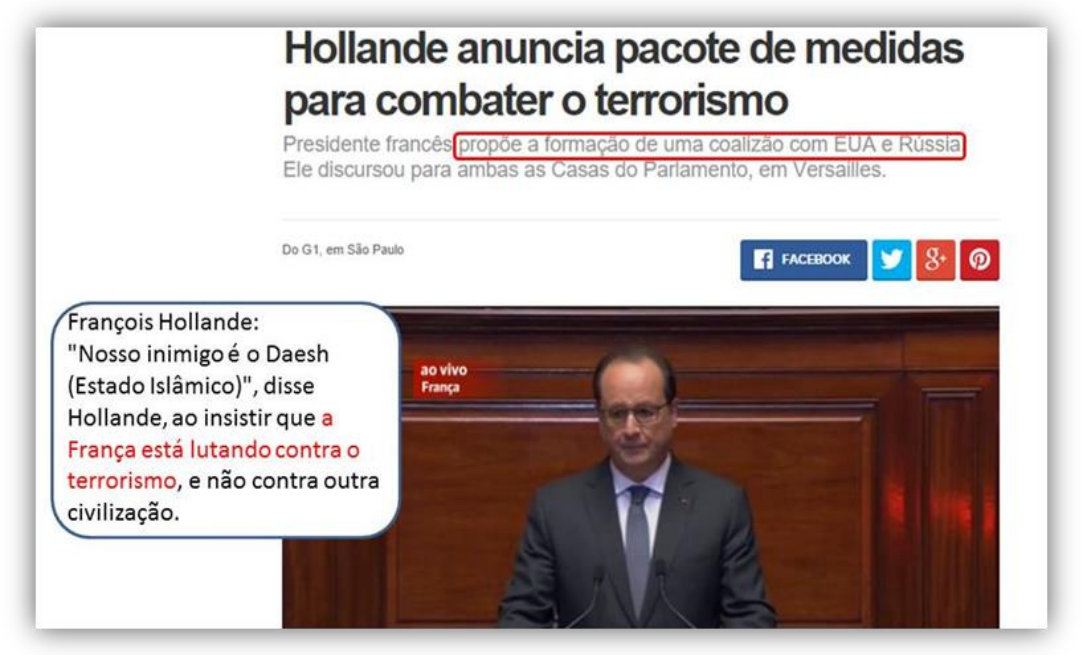

Figura 2: Screenshot Hollande anuncia pacote de medidas Fonte: Portal G1 $1^{5}$.

Qualquer motivação política, religiosa ou econômica fica eclipsada quando a jornada do herói é estabelecida em uma narrativa, onde um dos lados assume a

\footnotetext{
5 Disponível em <http://goo.gl/Of9hEJ>. Acesso em 02/02/2016.
} 
representação arquetípica do herói e o outro a do vilão ou de um desafio a ser superado. A premissa de uma luta eterna do "bem contra o mal" se instala em primeiro plano, na qual a tendência é sempre de que o "nós" seja a parte certa e o "eles" a parte errada.

Tendemos a estabelecer empatia com o herói que, dentro de uma lógica cognitiva, tem os objetivos claros. Por outro lado, tendemos a eleger um vilão a ser rejeitado, que geralmente é amorfo ou disforme, como os números, as multidões e outros produtos das generalizações e distorções da linguagem, pelo qual geramos aversão, antipatia, temor e, em casos extremos, ódio.

$\mathrm{Na}$ cobertura da tragédia ambiental ocorrida no município de Mariana, em Minas Gerais, em que se configurou o rompimento da barragem de contenção de dejetos de minério administrada pela mineradora Samarco, o enunciado do portal G1, no dia 05 de novembro de 2015, anuncia o evento categorizando a ruptura em questão como um "acidente". A construção da manchete denota que o fato se relaciona a um fenômeno de ruptura de causas imprevisíveis ou desconhecidas, como mostra a captura de tela na figura 3.

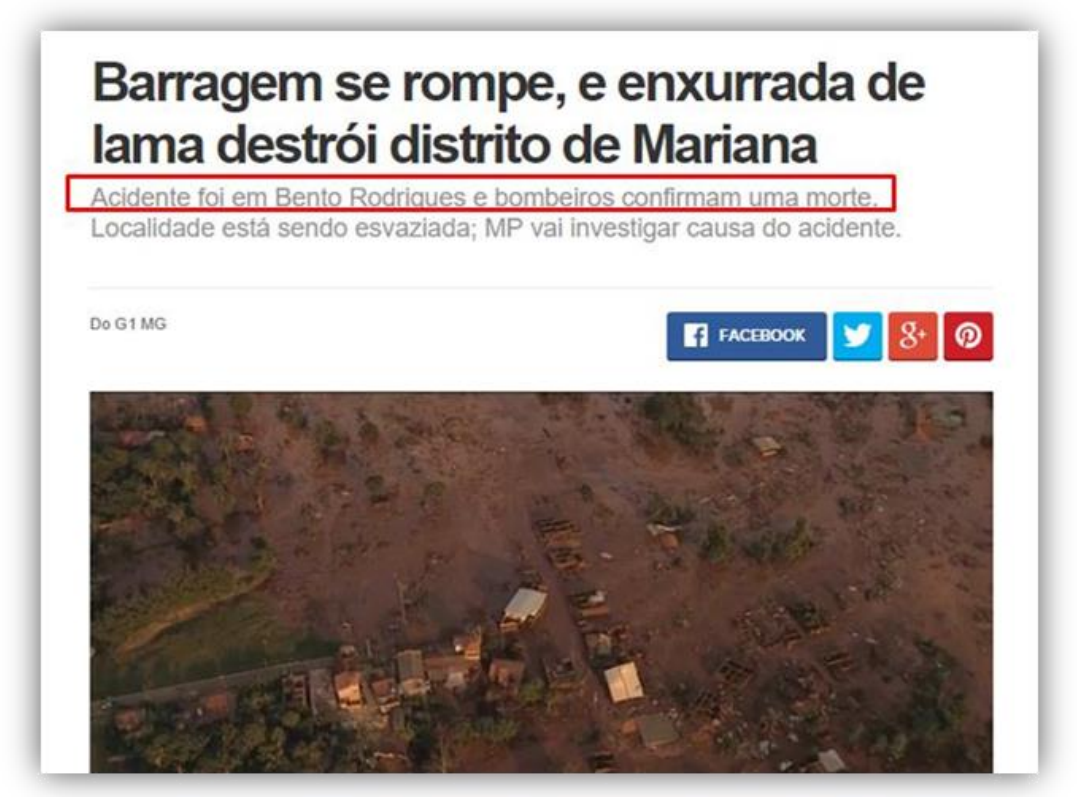

Figura 3: Screenshot G1 anuncia tragédia em Mariana.

Fonte: Portal $G 1^{6}$.

6 Disponível em <http://goo.gl/8S9niH>, Acesso em 02/02/2016. 


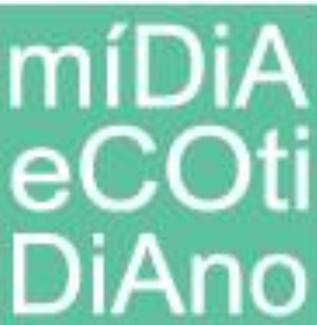

No caso, a narrativa do herói está presente ao longo do texto, na ação dos bombeiros que tentam ajudar as vítimas do ocorrido, sem que um vilão ainda esteja estabelecido. A figura do opressor, eclipsada do texto pela causalidade atribuída pela manchete, passa a existir como um espectro na cabeça do receptor, que vai buscar generalizações, omissões e distorções para estabelecer um distanciamento do possível causador da tragédia. A ausência do vilão faz com que o público "tateie" possibilidades dentro de seu mapa cognitivo, associadas a inimigos no seu imaginário particular, e alguns algozes são sugeridos pela rede de crenças dos receptores da notícia, como mostram alguns dos comentários retirados da mesma matéria, expostos na Figura 4.

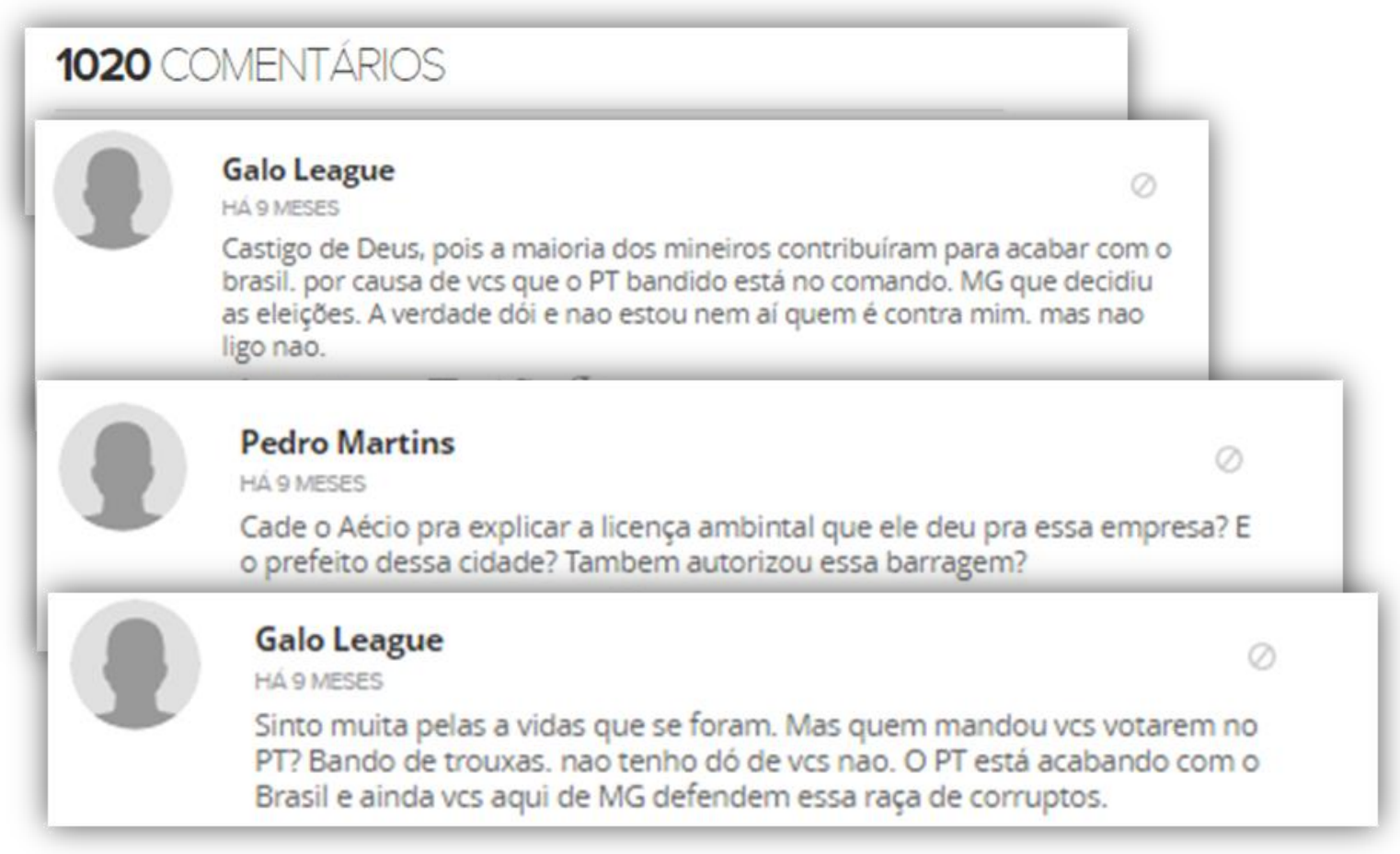

Figura 4: Screenshot G1 comentários da matéria tragédia em Mariana.

Fonte: Portal $G 1^{7}$.

A necessidade de completar os personagens básicos que compõem a jornada do herói, portanto, tende a acionar a rede de crenças do receptor da mensagem para que ele insira os elementos faltantes e necessários à vivência arquetípica.

7 Disponível em <http://goo.gl/8S9niH>. Acesso em 02/02/2016. 


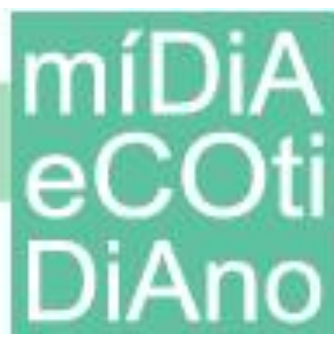

É claro que todas estas inferências são pequenas demonstrações de como a retorica midiática pode construir condições para a eliciação de emoções arquetípicas, gerando condições de emocionalidade que originem estados de ação no público receptor destas mensagens.

\section{Conclusão}

Ao construir uma retórica apoiada em factoides que eliciem estados arquetípicos, poderia a mídia manipular as emoções de seu público receptor para gerar empatia por determinadas figuras e situações em detrimento de outras? Será que o ethos, pathos e logos da construção retórica (REBOUL, 1998) focadas em necessidades arquetípicas poderiam ter maior aderência ao imaginário coletivo?

Um estudo mais aprofundado sobre a transposição da simbologia arquetípica para os atos de fala e atos de comunicação de massa poderia ajudar a responder a estes questionamentos, já que a retórica midiática parece querer recorrer mais às emoções do que à razão para construir significados.

Outra pergunta que brota desta constatação é: se as emoções são parte determinante no processo de significação, saber como eliciá-las a partir de uma construção narrativa orientada por referências arquetípicas não poderia ser uma fórmula de indução do público?

Por enquanto, parece aceitável concluir que a construção retórica, quando voltada a atender necessidades arquetípicas, ganha um maior poder de persuasão. Se esta premissa for verdadeira, podemos inferir que ganha poder aquele que constrói um discurso sobre os fatos que atente às necessidades arquetípicas do sujeito, tendo boas chances de ser considerado o "melhor discurso" justamente por eliciar emoções que são ativadas pela vivência de arquétipos.

A significação, já é sabido, não está sujeita somente aos fatos em si, mas também ao clima elaborado pela narrativa retórica para a interpretação dos fatos. Ou seja, está sujeita às condições de emocionalidade que são propostas pelos operadores retóricos utilizados na construção do conteúdo. 
A energia psíquica que, em tempos remotos e arcaicos, era destinada a nos manter vivos enquanto espécie frente às diferentes situações do ambiente, hoje é canalizada pelas narrativas estimuladas pela mídia. Liberada nas induções emocionais de filmes, novelas, jornais e outros construtos simbólicos, a energia se esvai e a sensação de realização reconforta a psique. Na sociedade hipermidiatizada, é no conforto das telas do cinema, da televisão, do computador, do smartphone etc. - que as necessidades arquetípicas são saciadas, e sensações de plenitude e satisfação dão sentido à existência.

Com esta constatação, evidencia-se que os estudos em comunicação devem se debruçar cada vez mais sobre os processos que eliciam emoções no sujeito, que vão desde a esferas de significação culturais e sociais até as esferas biológicas que configuram a psique humana.

\section{Referências}

ARISTÓTELES. Retórica. 1 ed., 2011, reimp. São Paulo: Edipro, 2013.

CAMPBELL, Joseph. O herói de mil faces. São Paulo: Pensamento, 1995.

COSTA, Jorge Campos. Filosofia da Lingüística, Filosofia da Ciência e Metateoria das Interfaces. Porto Alegre: 2007. Disponível em <http://www.jcamposc.com.br/ textos_disciplinas/filosofia_da_linguistica-filosofia_da_ciencia_e_metateoria_das_interfaces.pdf $>$. Acessado em junho de 2015.

DAMÁSIO, António. O mistério da consciência: do corpo e das emoções ao conhecimento de si. São Paulo: Companhia das Letras, 2000.

EKMAN, Paul. A linguagem das emoções. São Paulo: Lua de Papel, 2011.

JUNG, Carl Gustav. A dinâmica do inconsciente. Petrópolis, RJ: Vozes, 1991.

. Os arquétipos e o inconsciente coletivo. 7 ed., Petrópolis, RJ: Vozes, 2011.

. O homem e seus símbolos. Rio de Janeiro: Nova Fronteira, 2008.

. Psicologia do Inconsciente. 19 ed., Petrópolis, RJ: Vozes, 2011.

MARK, Margaret; PEARSON, Carol. O herói e o fora-da-lei: como construir marcas extraordinárias usando o poder dos arquétipos. São Paulo: Cultrix, 2001.

REBOUL, Olivier. Introdução à retórica. São Paulo: Martins Fontes, 1998.

STEIN, Murray. Jung: o mapa da alma: uma introdução. São Paulo: Cultrix, 2006.

YOUNG, Skip Dine. A psicologia vai ao cinema: o impacto psicológico da sétima arte em nossa vida e na sociedade moderna. São Paulo: Cultrix, 2014. 